Article

\title{
Aspects of Industrial Design and Their Implications for Society. Case Studies on the Influence of Packaging Design and Placement at the Point of Sale
}

\author{
Juárez-Varón David ${ }^{1, * \mathbb{D}}$, Mengual-Recuerda Ana ${ }^{2}$, Ferrándiz-Bou Santiago ${ }^{1} \mathbb{D}$ and Alarcón-Valero Faustino ${ }^{2}$ \\ 1 Department of Mechanical and Materials Engineering, Universitat Politècnica de València, Camino de Vera, \\ s/n, 46022 Valencia, Spain; sferrand@mcm.upv.es \\ 2 Department of Business Organization, Universitat Politècnica de València, Camino de Vera, s/n, \\ 46022 Valencia, Spain; anmenre1@upv.es (M.-R.A.); faualva@omp.upv.es (A.-V.F.) \\ * Correspondence: djuarez@upv.es; Tel.: +34-619-835-064
}

Citation: David, J.-V.; Ana, M.-R.; Santiago, F.-B.; Faustino, A.-V. Aspects of Industrial Design and Their Implications for Society. Case Studies on the Influence of Packaging Design and Placement at the Point of Sale. Appl. Sci. 2021, 11, 517. https://doi.org/10.3390/app11020517

Received: 11 November 2020 Accepted: 29 December 2020 Published: 7 January 2021

Publisher's Note: MDPI stays neutral with regard to jurisdictional clai$\mathrm{ms}$ in published maps and institutional affiliations.

Copyright: (C) 2021 by the authors. Licensee MDPI, Basel, Switzerland. This article is an open access article distributed under the terms and conditions of the Creative Commons Attribution (CC BY) license (https:// creativecommons.org/licenses/by/ $4.0 /)$.
Featured Application: This work aims to demonstrate that product design and packaging must be aligned with the point of sale and its social purpose.

\begin{abstract}
Manufacturing engineering is responsible for the design, development and improvement of production systems that convert raw materials into finished products. Each product is designed to be sold to numerous potential consumers, so the importance of the stimuli surrounding the product in packaging, and at the point of sale, cannot be underestimated. The environmental, social, and ethical commitments of industrial design (and their implications in manufacturing) are establishing universal principles in a common effort to foster a more harmonious and sustainable society. This work aims to analyse, through eye tracking biometric techniques, the level of saturation of information generated by the concentration of stimuli in packaging and the retail channel, possibly creating a lower level of attention towards the product itself. This research confirms that every product associated with a manufacturing process seeks to respond to a need, so the associated responsibility is significant. This would suggest that designers incorporate knowledge from multiple fields, including marketing strategies, design, research and development, basic knowledge related to production, integration management and communication skills. More than $50 \%$ of consumer attention is dedicated to other elements/items that accompany the product, so it is important to consider this in the design phase. The results can be used to improve efficiency in both generating product attention, and stimulus design for the purchasing process.
\end{abstract}

Keywords: design; manufacturing; engineering; packaging; distribution; society; eye tracking

\section{Introduction}

Consumer product design is a science, and an art. Science helps us meet any performance, reliability, manufacturability, innovation, and safety requirements. The art involves compromising these requirements as little as possible in filling the customer's needs while generating the best cost and profit from the effort [1]. The design process may be divided into different stages, starting from the definition of the customer needs, through the conceptual design phase and ending with the detailed design [2].

An increased and ongoing trend toward a greater variety of products can be observed in manufacturing industries [3]. The impact of the industrial transformations exceeds the production systems themselves; that is to say, they affect the entire value chain, from the product design and development process (PDDP) through manufacturing to marketing, and disposal $[4,5]$.

There must be a distinction between the two perspectives on products: that of the designer and that of the user. The designer focuses on functionality and appearance, because 
these two are the most relevant for understanding the relationship between emotion and design [6]. From the perspective of the user, functionality and appearance are important, because these two aspects of the design are the principal sources of affective reactions.

Design defines objects and establishes approximations [7], since it is a creative act that works with the intangible to create meaning at different cultural levels [8-10]. However, technologies allow the design and manufacturing of an almost free-form geometry, which can be used to create more complex, multi-function or multi-feature products [11].

There is a current trend towards prioritizing the application of a sustainable product design [12]. Remanufacturing is also one strategy that salvages the value put into products during manufacturing and thus reduces the environmental impact of products throughout their life-cycle $[13,14]$.

\subsection{Industrial Design}

Industrial design is a holistic approach to problem solving. Design should incorporate three main elements: the technological component, the business component, and the creative component [15]. It is, above all, multidisciplinary [16-18]. Sustainable Development Goals, an initiative promoted by the United Nations [19], must be a fundamental element in the role of the designer within companies. The work done by a designer requires time, research, analysis, knowledge of trends, materials, manufacturing processes and understanding of all the inherent limitations. Industrial designers must incorporate knowledge from multiple fields, including marketing strategies, design, research and development skills, basic knowledge related to production, integration management and communication skills [20].

At the same time, concerns about social and environmental impact are increasing [21]. Every product, designed to be sold, is associated with a manufacturing process, and seeks to respond to a need, so the associated responsibility is high. The role of marketing and product design helps drive the firm's performance [22]. Design orientation is stimulated by proactive market orientation and by marketing-design integration during the development of new products. For many consumer goods, the visual appearance is a vital determinant of market success [23,24].

The analysis of consumer behaviour is increasingly important in the design of new products, with relationship-based learning and its implications for customer engagement during the design stage of the new product development process [25]. The use of big data allows designers to learn progressively from new design cases, in which design factors and the emotional requirements of consumers are interrelated [26,27]. Product ecosystems enable user sensing, setting the stage for the control of post-purchase consumption patterns [28].

Considering the social impact of products allows for additional insights into product design. Social impact assessments (SIA) and social life cycle assessments (SLCA) are two of the most common processes discussed in the literature to evaluate social impact. Processes should be developed to help designers consider the social impact of their products [29].

\subsection{Consumer Behaviour}

The changes in people's shopping and consumer needs and habits, combined with the growing relevance of the "novelty" factor $[30,31]$ and their implications in terms of innovation [32], design and product life cycle [33] are factors that have led to the transformation of the competitive situation over the last twenty years [34].

The importance of packaging design, together with the in-store shopping experience (based on projected stimuli), has continually increased to add value to the product design itself, especially in recent times, in industrial key sectors, such as toys and footwear.

The main objective of packaging design is to engage potential consumers and be a communication tool in marketing $[35,36]$. Packaging has an influence on purchasing decisions [37] and communicates product information [38], and is a unique tool to differentiate a product from its competitors within the store and to reflect the quality and characteristics 
contained in the product [39]. The design and configuration of the packaging has a direct impact on the consumer's shopping experience. Through form, texture, objects, colour and intensities, packaging can stand out and serve as a tool to attract the consumer's attention [40-42].

Nowadays, both online and in-store, for packaging to be effective, it has to create a better visual impact than the competitors and to generate a higher level of attention than other companies. The change in brand location [43], images and instructions [44] on the packaging are directly related to appearance and are a positive factor in providing specific responses to consumers, such as an immediate desire to buy [45], and own the product [46] or a greater willingness to pay for it [47].

Although packaging, as an element of integral design, has not been so deeply researched. Studies such as that of Reimann [45] have used a new approach to evaluate packaging from the perspective of neuroscience.

There is currently a rising interest in research about the influence of perceptual characteristics measured using neurophysiological tools. Disciplines that apply neuroscientific techniques such as "consumer neurosciences" have led to the development of neuromarketing, which allows market research to be conducted in a different way [48-51], through the analysis of consumer responses to advertising stimuli [52-55], brands, music, etc. [10,56]. The advances in neurosciences, neurobiology and neuropsychology in recent decades have allowed us to understand how the brain works [57], how we interpret the world we live in and what is more important, how we interact and the way we make decisions [58].

The objective of this study is to analyse aspects of the global design of the product (including stimuli associated with it) and its impact on consumer attention to the product, providing guidelines that help improve the overall design of the product, taking into account factors such as packaging and the point of sale.

Percentage of attention to the product, compared with the attention intended to other elements, must be taken into account in the design process for the sale of the product to be effective, and it is important to have this information so that the design of products and their manufacture obtain the level of efficiency necessary to generate a high impact in society, minimizing failure in the design and launch of new products.

\section{Materials and Methods}

The aim of these two studies (toy and footwear) is to determine the time that the user dedicates to the product, compared to other factors that help make the purchasing decision, such as messages, accessories, decoration, brand, etc.

Toy case (packaging).

The aim of this work is to determine, through eye tracking techniques, the cognitive perception that Spanish parents, between 35 and 45 years old, with children between 4 and 8 years old, have regarding the elements included in the design of toy packaging that is educational and, age appropriate for children. To do this, we used eye tracking techniques that allowed the attention of the subjects to the stimuli to be analysed.

Footwear (store).

The aim of this research was to determine, through eye tracking techniques, the cognitive perception of consumers, between 30 and 55 years old, with a medium-high socioeconomic level, who like to travel to shop in store and value the concept of design, quality and fashion in footwear. The level of attraction towards the brand and predisposition towards the purchase is linked to the influence of the stimuli projected in the store. All other aspects (local distribution, employees, and product) remain constant. To do this, we used eye tracking techniques which allowed the attention of the subjects to the stimuli to be analysed. 


\subsection{Objectives}

This research work helps to answer the question of what aspects are most relevant, visually, for consumers when buying products, taking into account the packaging and the environment in which they are offered.

Toy case (packaging).

This research work is focused on educational toys, which will obviously be quite different from more general leisure products. This empirical research focuses on an educational toy distributed in Spain by the Educa brand (Conector family, reference "I learn English"), which is the brand's best seller in this market area. The product is the toy itself, and everything else is messages provided by the brand. The study looks at customer eyes' reactions when looking at the packaging, measuring ocular activity generated by different aspects of packaging design.

The specific objectives are as follows:

- Analyse and segment the areas, according to social circumstance.

- Analyse the attention of the different elements generated in the parents, according to the purchase intention.

Footwear (store).

This research work helps answer the question of which stimuli in a standard store of a quality fashion footwear brand (products made with leather), with a high average price (100-180 euros) have greater efficiency in capturing the attention of the gaze. The experience was carried out in a store belonging to the Pikolinos footwear brand, one of the best positioned Spanish brands in Spain and with an international projection, located in Alicante (Spain), with an average size of 35 square meters.

\subsection{Research Instrument}

In this study, the research techniques used are eye tracking biometrics and a qualitative study. Advances in technology allow this new field to go beyond traditional quantitative and qualitative research tools, and focus on consumers' brain reactions to marketing stimuli [59]. It is a new discipline that applies knowledge of the latest brain-activity research to the world of management [60]. Ariely [61] states that the main objective of marketing is to facilitate linking products and people. Eye tracking biometrics research aims to connect activity in the neural system with consumer behaviour, and has a wide variety of applications for brands, products, packaging, advertising or marketing for stores, to be able to determine the most attractive products, level of novelty or awareness.

Consequently, the biometric technique that has been used in this study is eye tracking. Its purpose is to measure the cognitive processing of the stimuli designed, which records the visual attention of the subjects towards the areas of interest (AOIs).

\subsection{Sample}

Toy case (packaging).

The sample consisted of men and women, according to the indications of the manufacturer Educa, from current consumer data. A total of 30 people (33\% men and $66 \%$ women) participated randomly and voluntarily as study subjects after meeting the requirements of being parents aged between 35 and 45 with children of ages between 4 and 8 years old. Alicante (Spain) was chosen for the sample due to its status as a provincial capital. The sample size (consisting of 10 men and 20 women) was adequate for this study $[62,63]$. After carrying out the empirical study, 5 users (all belonging to the female gender) were discarded, leaving 25 users (10 men and 15 women).

Footwear (store).

In the present research, the sample consisted of men and women, according to the profile of the target indicated by the brand for the current consumer. A total of 30 people (33\% men and 66\% women-percentages indicated by the brand, according to real market demand) participated randomly and voluntarily as study subjects after meeting the requirements of being between the ages of 30 and 55 and with a medium-high socioeconomic 
level, and who were return customers of the brand (having bought a product at least once). The location of the study was in the Pikolinos Store in Alicante city (Spain), monitoring subjects of various origins when they were in front of the main seasonal product area. The study was structured in 1 phase, with the sample size (consisting of 10 men and 20 women) suitable for this study $[64,65]$.

\subsection{Data Collection and Analysis}

The independent variable was the sex of the participants, with a similar sociocultural profile in all of them, and determined by the main profile of the company's target. The dependent variables were the level of attention and the emotional arousal peaks recorded in response to the observed stimuli.

Quantitative data analysis was used to evaluate the seconds that elapsed between the appearance of the stimulus and the first fixation, or the Time First Fixation (TFF), the number of eye fixations, or the Fixation Count (FC), and the total number of seconds of attention to each area of interest, or Total Fixation Duration (TFD). The qualitative evaluation was performed using thermal maps of the attention registered by the eye tracker.

Regarding the semi-structured in-depth interview, the interview protocol was designed to provide evidence of the experience of buying these categories of product. The interviews were carried out by the authors. All interviews were conducted face-to-face, recording the electrodermal activity. All interviews were videotaped, transcribed, and analysed. The application of neuromarketing to qualitative research allows researchers to make a record of the arousal, or general physiological and psychological activation of the body [66], experienced by the subject during an in-depth interview and neuro-qualitative study [64]. All interviews were videotaped, transcribed, and analysed.

The GSR peaks, which can occur up to $3 \mathrm{~s}$ after the start of emotional activation were used to determine emotional arousal during the in-depth interview.

The qualitative research phase (in-depth interviews) was monitored using the Shimmer3 GSR galvanic skin response model. ConsensysPRO v1.6.0 software was used for data collection.

Toy case (packaging).

Certain products, such as board games, are shown to the consumer on the shelf, along with other equivalent products. Only the packaging is accessible, and the consumer has to handle it to be able to view it in full. For this reason, the image of the packaging was projected to the users and the eye movement was recorded through desktop eye tracking equipment. The research phase with packaging was performed using the eye tracker model Gazepoint GP3HD, with a $150 \mathrm{~Hz}$ sampling rate. For data collection, Gazepoint Analysis UX Edition v.5.3.0 software was used.

The statistical analysis of the data was performed with the R software, v.3.6.3. The common element (stimuli) was defined, as well as areas of interest (Figure 1 and Table 1). Subjects were exposed to 1 package containing 7 stimuli, with a maximum time limit of $30 \mathrm{~s}$ to prioritize the areas of interest that captured the most attention [67].

The area sizes of AOIs are different, according to the manufacturer design proposal. The AOIs are on the front design of the packaging, and the image of the product (the toy) is within the AOI 07.

Footwear case (store).

In order to show the same stimulus to all users, an image of the area of interest was captured. The research phase with packaging was performed using the eye tracker model Gazepoint GP3HD, with a $150 \mathrm{~Hz}$ sampling rate. For data collection, Gazepoint Analysis UX Edition v.5.3.0 software was used. 


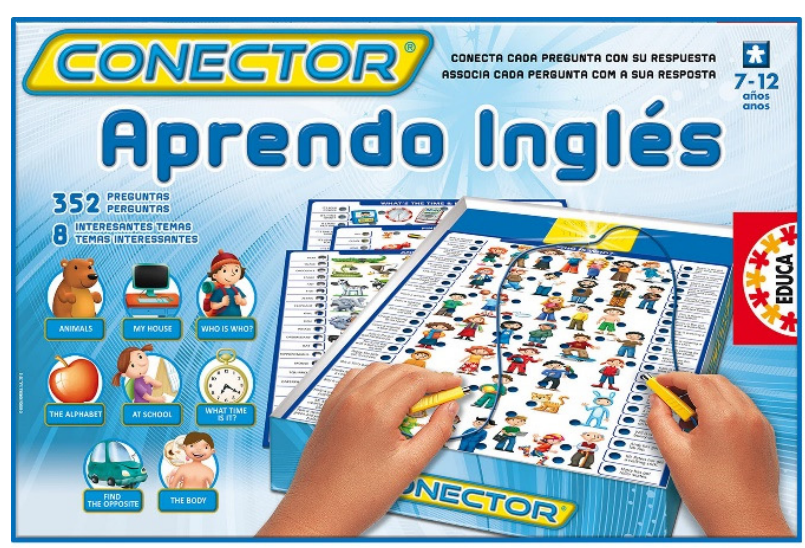

(a)

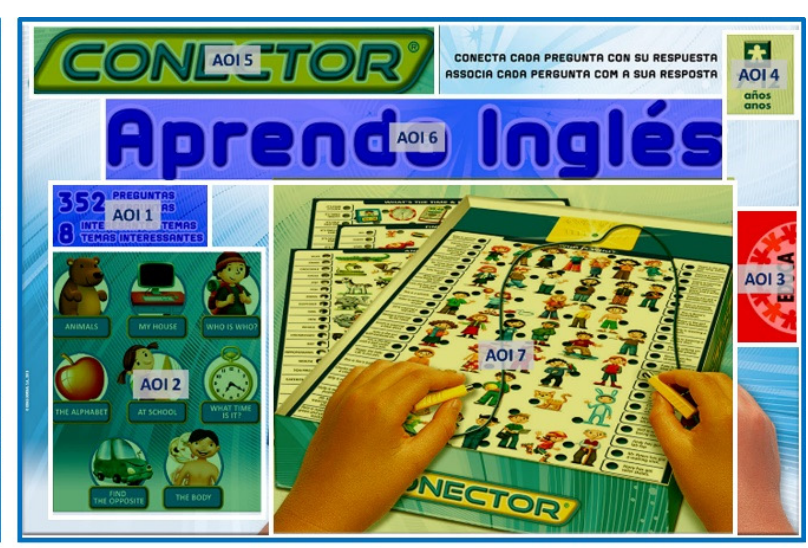

(b)

Figure 1. Toy packaging (a) and Areas of Interest (b). Source: Prepared by the authors.

Table 1. Toy packaging. Areas of Interest and description.

\begin{tabular}{cc}
\hline AOI Number & AOI Name \\
\hline AOI 01 & Number of questions/topics \\
AOI 02 & Game topics \\
AOI 03 & Trademark \\
AOI 04 & Recommended age \\
AOI 05 & Product family \\
AOI 06 & Product name \\
AOI 07 & Product picture \\
\hline
\end{tabular}

The statistical analysis of the data was performed with the R software, v.3.6.3. Common elements (stimuli) were defined for all consumers (volunteers). The subjects were exposed to an exhibition area, structured into 25 stimuli (Figure 2 and Table 2). Subjects received instructions about the area of the store shown, to prioritize the areas of interest that captured the most attention [67].

Table 2. Footwear store area. Areas of Interest and description.

\begin{tabular}{cccc}
\hline AOI Number & AOI Name & AOI Number & AOI Name \\
\hline AOI 01 & Small video Screen (Decoration) & AOI 14 & Product \\
AOI 02 & Hanging papers (Decoration) & AOI 15 & Product \\
AOI 03 & Vertical garden & AOI 16 & Product \\
(Brand/Decoration) & AOI 17 & Product \\
AOI 04 & Wood boxes (Decoration) & AOI 18 & Product \\
AOI 06 & Decoration & AOI 19 & Product \\
AOI 07 & Decoration & AOI 20 & Product \\
AOI 08 & Accessories & AOI 21 & Product \\
AOI 09 & Accessories & AOI 22 & Product \\
AOI 10 & Product & AOI 23 & Product \\
AOI 11 & Product & AOI 24 & Product \\
AOI 12 & Product & AOI 25 & Product \\
AOI 13 & Product & & \\
\hline
\end{tabular}


(a)

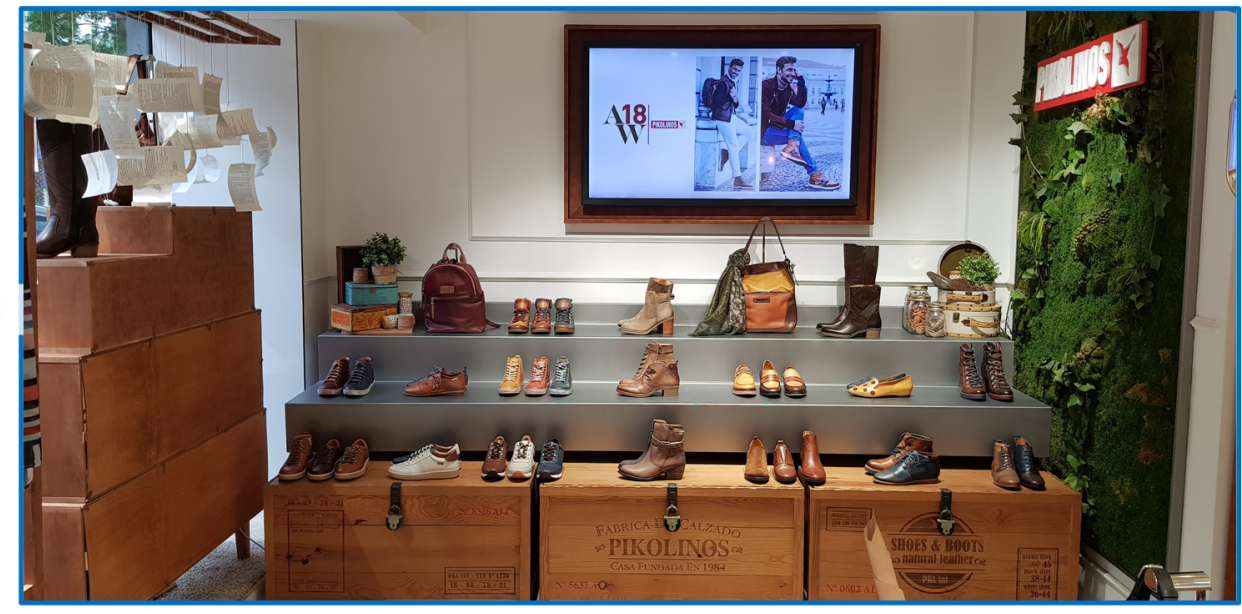

(b)

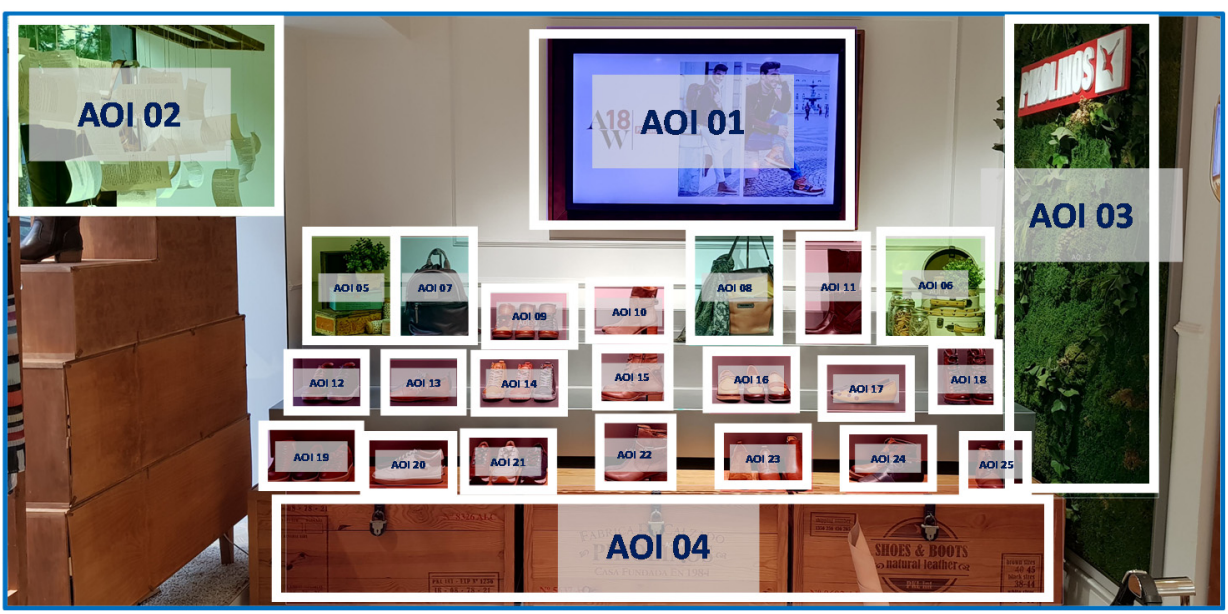

Figure 2. Footwear store area. Original image (a) and Areas of Interest (b). Source: Prepared by the authors.

Special stimuli designed by the brand for the store, with the aim of enhancing the values of the brand, are the vertical garden (representing nature), shop furniture, small video screen, wood boxes and hanging papers.

\section{Results}

\subsection{Comprehensive Analysis of Attention}

The Kruskal-Wallis test was used to show that visual attention is greater in women than in men [62]. The following measurements were used: Average Fixation Duration (AFD), total number of fixations, and frequency of fixations per second, total time of fixations. Kruskal-Wallis' method has shown that the total number of fixations and the total time of fixations are greater, with significant differences for women than for men as can be seen in Table 3 .

Table 3. Test of Kruskal Wallis $\left({ }^{*} p<0.01\right)$.

\begin{tabular}{ccc}
\hline Eye Tracking Metrics & Men & Woman \\
\hline Average fixation duration $(\mathrm{ms})$ & 256 & $351^{*}$ \\
Total number of fixations & 956 & $1102^{*}$ \\
Fixations per second & 1.05 & $1.45^{*}$ \\
Total time of the fixations & 774 & $989^{*}$ \\
\hline
\end{tabular}


Toy case (packaging).

The heat maps produced by the attention of the participants on the different stimuli of the areas (Figure 3), qualitatively reflect more intense attention on the stimuli and the information on the product, and, to a lesser extent, on the stimuli associated to brand or decoration.

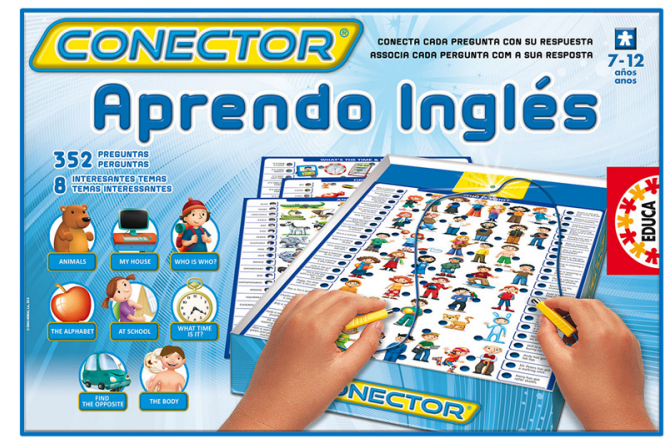

(a)

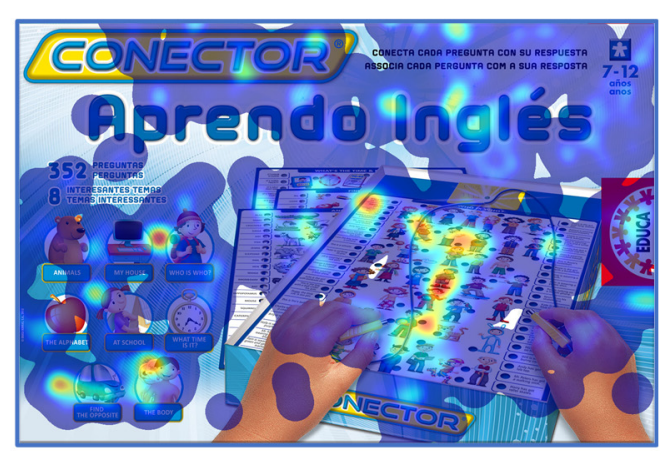

(b)

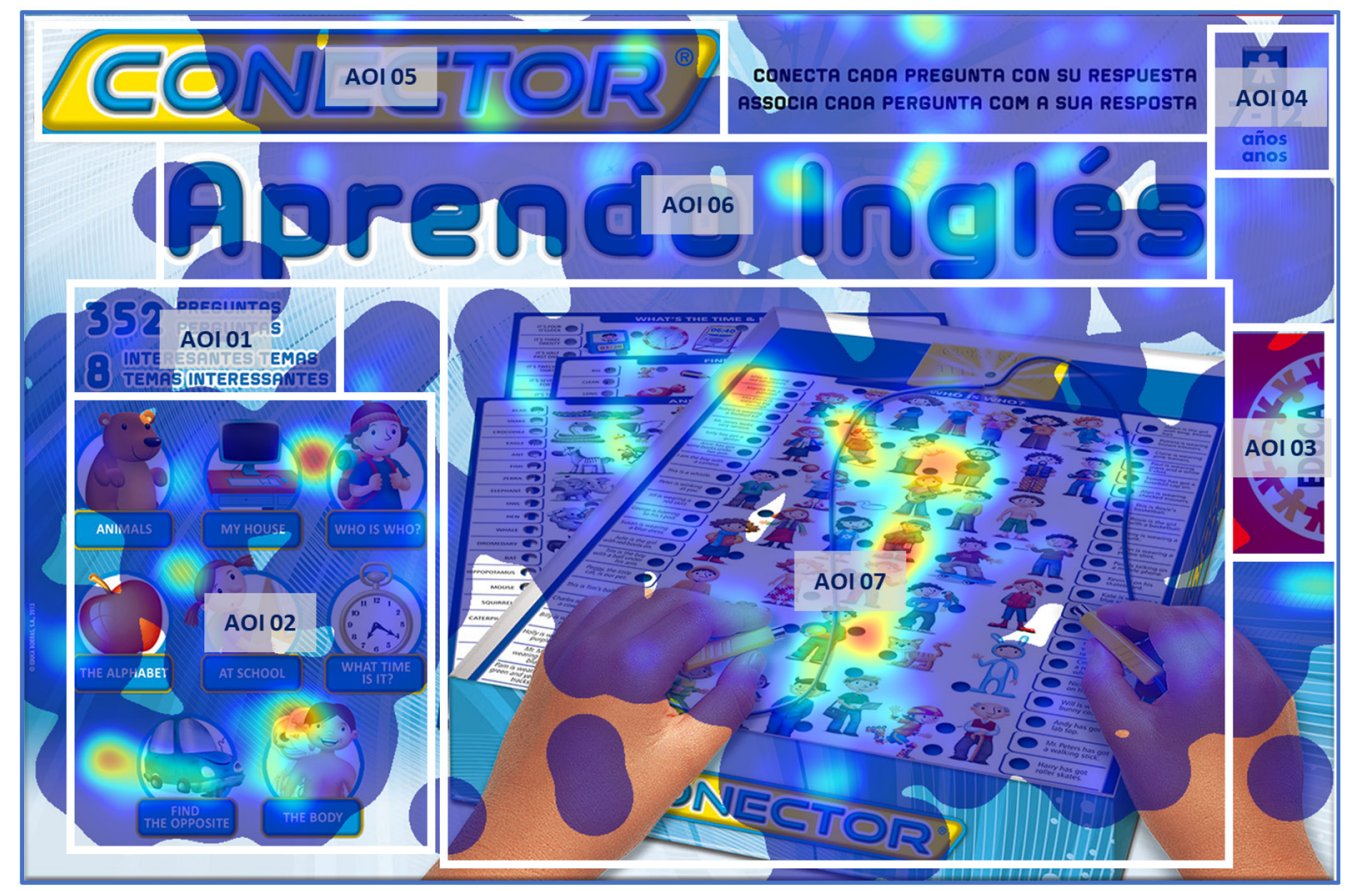

(c)

Figure 3. Toy packaging original image (a), heat map (b) and heat map with AOIs (c). Source: Prepared by the authors.

In the first comprehensive quantitative analysis of attention that the entire group of subjects showed towards stimuli (Table 4), it was observed that the image of the game (AOI 07) attracted the highest percentage of attention of all the participants. The AOI 02 (themes of the game) is the second in percentage of attention. Stimulus 01 (number of questions) reflects a high percentage of attention.

Footwear case (store).

The heat maps produced by the attention of the participants on the different stimuli of the areas (Figure 4), qualitatively reflect more intense attention on the stimuli and the information on the product, and, to a lesser extent, on the stimuli associated to brand or decoration. 
Table 4. Toy packaging. Time to First Fixation (TTF) and attention percentage of the total number of participants to each AOI. Source: Prepared by the authors.

\begin{tabular}{|c|c|c|c|c|}
\hline AOI Number & AOI Name & TTF (s) & Average Revisits & Attention Rate (\%) \\
\hline 1 & $\begin{array}{c}\text { Number of } \\
\text { questions/topics }\end{array}$ & 7.63 & 6 & 5.97 \\
\hline 2 & Game topics & 5.67 & 15 & 16.80 \\
\hline 3 & Trademark & 12.82 & 2 & 1.47 \\
\hline 4 & Recommended age & 9.30 & 3 & 2.26 \\
\hline 5 & Product family & 5.50 & 4 & 2.45 \\
\hline 6 & Product name & 2.68 & 10 & 6.66 \\
\hline 7 & Product picture & 1.05 & 26 & 26.17 \\
\hline
\end{tabular}

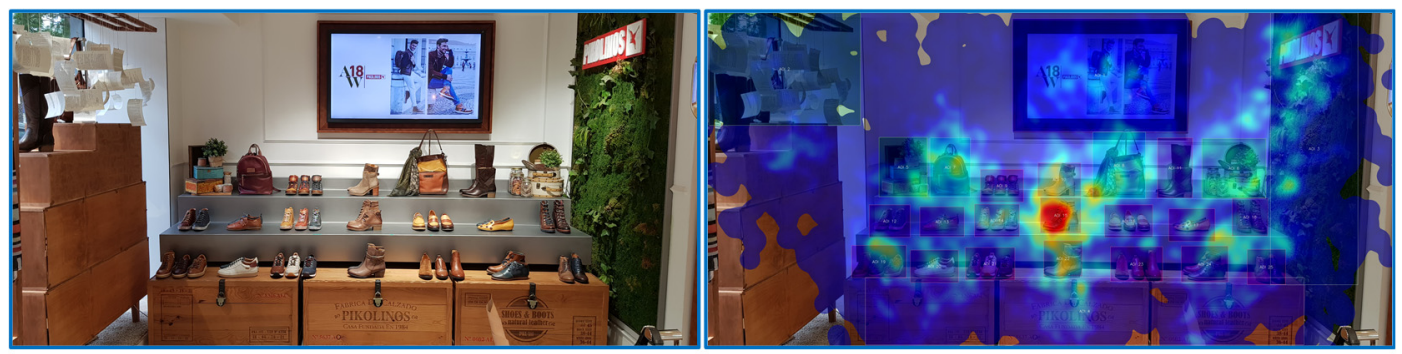

(a)

(b)

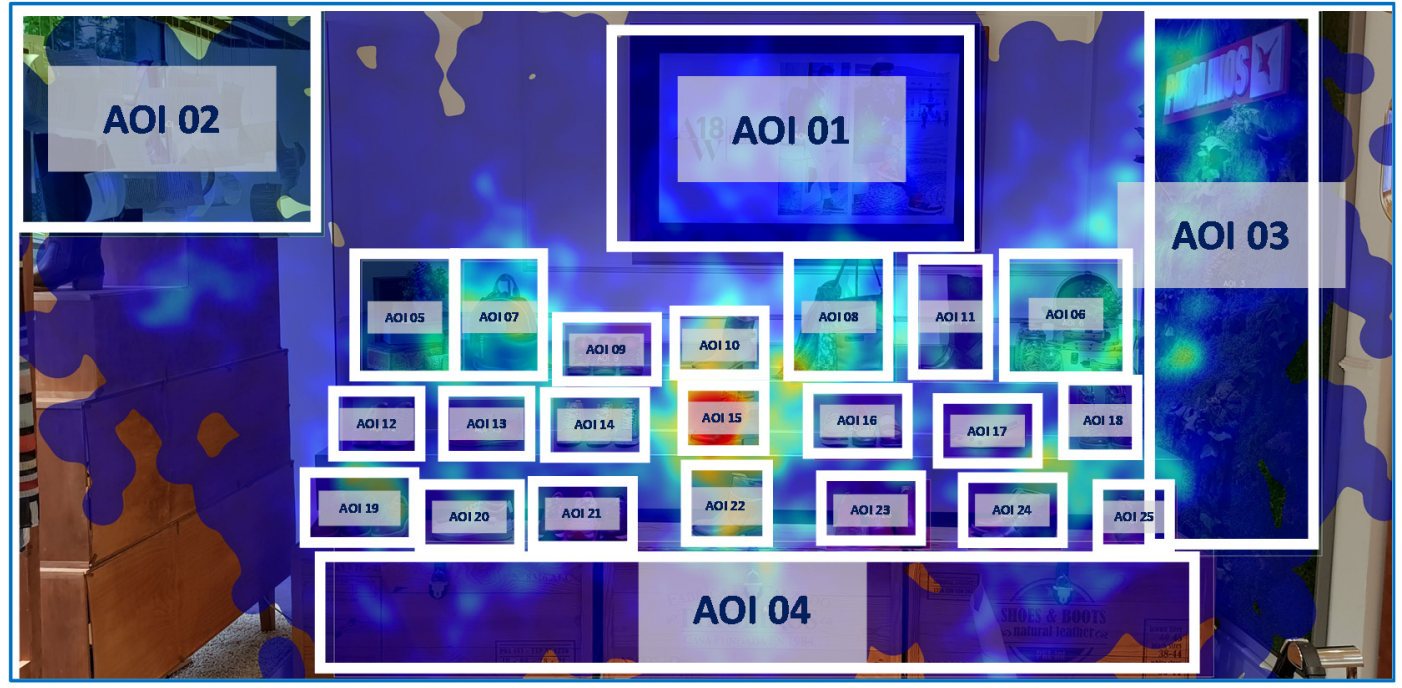

(c)

Figure 4. Footwear store area original image (a), heat map (b) and heat map with AOIs (c). Source: Prepared by the authors.

Analysing the attention time, Figure $4 \mathrm{c}$ and Table 5 indicate the level of importance of AOI 01, compared to the following two. The AOI 01 is the one that is given the most attention. The AOI 02 and AOI 03 zones have equal importance, although the table in AOI 03 has some value (but not significant when compared to AOI 02). 
Table 5. Footwear store area. Time to First Fixation (TTF) and Attention percentage of the total number of participants to each AOI. Source: Prepared by the authors.

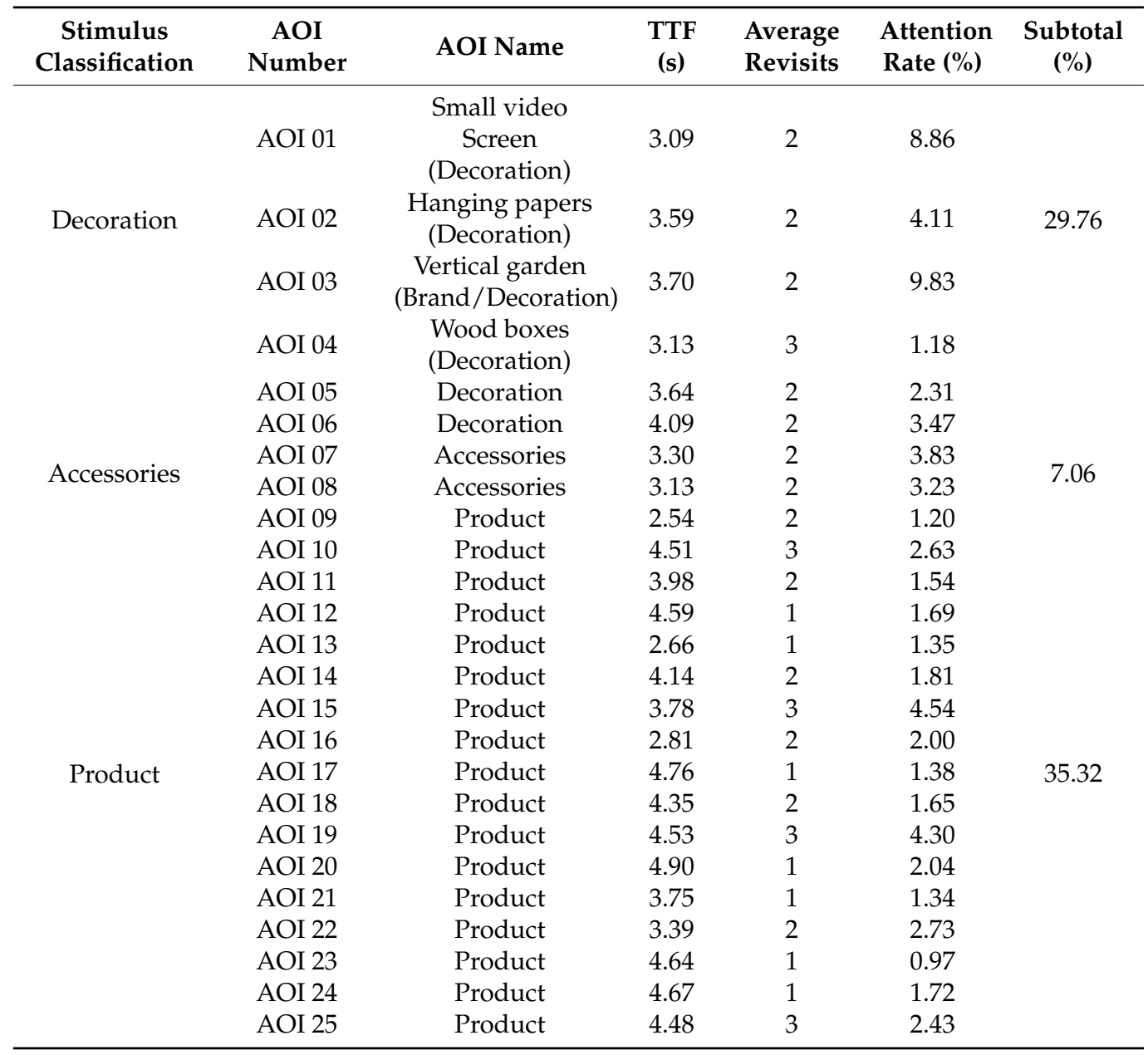

In both cases, the element that has been looked at in the first place (TTF) is the product itself, but afterwards the gaze has been diverted to other stimuli that accompany the product.

For both packaging and store area, the analysis of the attention rate (\%) dedicated to the product, relative to other elements, is shown in Figure 5.

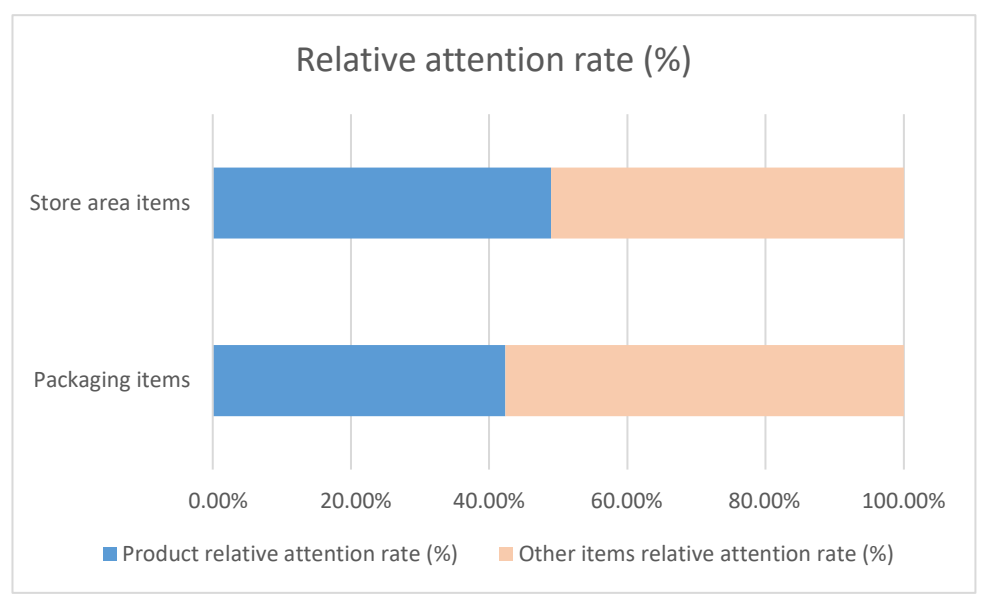

Figure 5. Attention rate (\%) dedicated to the product, relative to other elements, for both packaging and store area. Source: Prepared by the authors. 
The previous data about group behaviour regarding attention to the product (Table 6) showed that in the case of toy packaging it is lower than in the footwear store area. A significant percentage of attention is dedicated to other elements/items that accompany the product, so it is important to consider this in the design phase.

Table 6. Attention percentage of the total number of participants to the product, relative to other elements, for both packaging and store area. Source: Prepared by the authors.

\begin{tabular}{ccc}
\hline & $\begin{array}{c}\text { Product Relative Attention } \\
\text { Rate (\%) }\end{array}$ & $\begin{array}{c}\text { Other Items Relative } \\
\text { Attention Rate (\%) }\end{array}$ \\
\hline Packaging items & 42.36 & 57.64 \\
Store area items & 48.96 & 51.04 \\
\hline
\end{tabular}

\subsection{Qualitative Research. In-Depth Interviews}

At the end of the biometry part, an in-depth semi-structured interview was carried out. The questions asked in the interview are related to the overall experience. There was a first phase of open-ended and natural recall questions (about the experience) and a second phase of suggested recall questions. During the qualitative study, users were asked about the most important and influential aspects in procurement processes and were compared with data registered biometrics.

Toy case (packaging).

The questions were structured in 3 parts:

Section 1: Purchase process. Intention for buying educational toys (For your child, to give away, another) and, in order of priority, the criteria that the consumer would most take into account when purchasing an educational toy. (recommended age, theme, package messages; others).

The prevailing purchase intention was "For your child", along with "To give away". The recommended age and theme were key in choosing an educational toy, in that order.

Section 2: Natural Memory Questions. Concept, brand, and name of the toy.

Most remembered Educa, from their childhood. They did not remember the name of the toy. Some consumers remembered it in a distorted way.

Section 3: Perception of educational value through packaging.

Users indicated that Educa has a high educational value, for two reasons: the brand name and the experience lived in childhood. Regarding the price, the average value suggested was 15 euros.

These questions were asked to all the participants at the end of the experimental part, while the galvanic response of the skin was monitored. The objective was to locate the body changes that reflect the emotional state or somatic markers [68]. The somatic marker facilitates and speeds up decision-making, especially in social behaviour, where situations of greater uncertainty can occur [69].

The GSR peaks showed the highest emotional intensity (arousal) when expressing the reason for purchase. Social pressure (in the case of buying the toy with the intention of giving it away to a third party) determines that price is the key factor (the more expensive, the better), since it fits the budget and looks better. However, when it is for your own child, it is the educational factors.

Footwear case (store).

The questions were structured in 2 parts:

Section 1: Natural Memory Questions. Some detail that has attracted attention and why, some aspect to improve in the observed area. Most remembered the vertical garden, and the hanging papers.

Section 2: Suggested Memory Questions. Some detail that has attracted attention and why, and adaptation of the decoration to the style of the design and the brand. Some remembered particular shoes, and a particular accessory. Respect to the adaptation of the decoration to the brand style, most of the consumers agree with it. 
No special peaks were registered, due to the fact that no special stimuli were projected by the brand or no special situation described for the purchase process.

\section{Discussion}

For the packaging experience, the heat maps produced by the attention of the participants on the different parts of the packaging qualitatively reflect more intense attention on the graphic elements [38], and to a lesser extent, on the brands that advertised or the name of the game, key in the purchase decision [37].

In the first comprehensive quantitative analysis of the attention that the entire group of subjects showed towards stimuli [70] it was observed that the image of the product [43] attracted the higher percentage of attention of all participants [71]. The messages with a graphic component are the second in percentage of attention [39]. The number of questions (important anchor for parents, when quantifying the educational potential of the game) reflects a high percentage of attention. The designs with graphic shapes, again generates a higher percentage of attention.

The areas of interest analysed show the focused attention of consumers based on data and statistics [72]. These focuses of attention (main areas of interest displayed) have been endorsed by consumers through a qualitative study (in-depth interviews), are decisive elements in the purchasing process. The areas of interest analysed which show the highest percentage of attention (the cover image of the game, the number of questions and topics, as well as the recommended age) are decisive in the decision to purchase [73], since they transmit the child's experience, entertainment and expected level of learning. This approach must be complemented by the conclusions obtained in the in-depth interviews, which highlight a key insight when the product is going to be a gift: the price.

For the footwear store experience, the first part of the study analyses the intersection between consumer behaviour, experiential marketing and fashion footwear [74], with the aim of designing a guide of recommendations for the design of the most appropriate strategy to meet the needs of fashion footwear consumers [75]. In this area, eye tracking biometrics is extremely useful since it allows us to efficiently obtain the knowledge, objectivity and precision in the information, as well as the quality of the results [76].

With respect to the information obtained from the application of the eye tracking technique [77], it is worth commenting that the common denominator in the AOIs of greater attraction is the presence of the product, cancelling out attention to other decorative elements which pass unnoticed.

From the application of traditional marketing (in-depth interview), it should be noted that the experience in general was rated by everyone as good and enriching, since consumers consider that their expectations were met (Ran, Wei and Li, 2016). However, consumers are delighted when they have lived an experience that meets their expectations [78]. Sensory stimulation positively influences the brand experience and its value, which favourably affects the purchase intention [79] or evokes feelings associated with the brand [80]. It is important to understand how consumers experience brands [81]. The design orientation fully mediates the effect of proactive marketing orientation on perceived effectiveness [22].

\section{Conclusions}

The main objective of this study was to determine the degree of attention perceived by the product in the packaging (educational toy case) and at the point of sale (fashion footwear case) with the target audience and the effect that caused by these additional elements to the product in the consumer (target) in the purchasing process [48], and its possible effects on the perception of design by society, all of which will have a direct impact on the efficiency of the design and consequently on the success of the product.

The methodology performs a global analysis of the shopping experience [82], using qualitative research techniques and neuroscience biometrics technology. It is possible to analyse the mixed construct type "experience" of a consumer, in response to the presen- 
tation of stimuli in the environment in which the products will be communicated, using equipment and knowledge of neuroscience.

This study has revealed the suggested purchasing and consumption habits [50], the most valued aspects in the consumption of these products, product recall levels, perception of the product's value through packaging and stimuli at the retail channel [36]. It has also allowed the authors to identify the level of visual attraction (time spent) towards the product and towards other elements that accompany it (average exposure times in the areas of interest) and analyse the levels of value perceived by the target customer [83].

The greatest contribution of this research has been to identify that the level of saturation of information generated by the concentration of stimuli in the packaging and the retail channel [84], causes a lower level of attention towards the product itself, but provides complementary information about the brand and about the product itself, which can condition social behaviour and the shopping experience [85]. Consumer habits change, and organizations must design strategies for each contact they make with their consumers, through all the aspects that accompany the brand, generating a link through the stimulation of the senses and experiences with high emotional level, without saturating them, to achieve a greater perception of these creative products.

Designers have more control over users' visceral (perceptually-based) and behavioural reactions (expectation-based) than over reflective (intellectually-based) ones [6]. This analysis will help, considering the design process, to improve the product's consumer perception, throughout the design of additional stimulus around it.

As limitations of the study, indicate that results may be determined by the peculiar graphic solution of the packaging or the environment that define the selected cases. The different visual attributes could lead to different results-for example, with a different hierarchy (distribution of weights), simpler composition or a new colour or typographic palette (in the case of the toy packaging, specifically). It is important to specify that the visual language of both stimuli influences, in some way, the results obtained.

An interesting future path of research in this same field is analysing if the brand gets less attention because of its size or due to the brand condition itself. For a greater breadth of study, even the graphic characteristics of each part could be studied in a deeper way.

Author Contributions: Conceptualization, J.-V.D. and M.-R.A., methodology, J.-V.D.; software, M.-R.A.; validation, J.-V.D., M.-R.A. and A.-V.F., formal analysis, F.-B.S. and A.-V.F.; investigation, J.-V.D.; resources, J.-V.D.; data curation, M.-R.A.; writing—original draft preparation, M.-R.A. writing-review and editing, F.-B.S. and M.-R.A.; visualization, A.-V.F.; supervision, J.-V.D.; project administration, F.-B.S. and J.-V.D. All authors have read and agreed to the published version of the manuscript.

Funding: This research did not receive any specific grant from funding agencies in the public, commercial, or not-for-profit sectors.

Institutional Review Board Statement: The study was conducted according to the guidelines of the Declaration of Helsinki, and approved by the Ethics Committee of UNIVERSITAT POLITĖCNICA DE VALÈNCIA (date of approval: 23 October 2018).

Informed Consent Statement: Informed consent was obtained from all subjects involved in the study.

Data Availability Statement: The data presented in this study are available on request from the corresponding author. The data are not publicly available due to privacy.

Conflicts of Interest: The authors declare no conflict of interest.

Ethics Statement: This study was reviewed and approved by the Research Ethics Committee of the Universitat Politècnica de València (UPV). All participants gave their written informed consent. Subjects were informed of their voluntary participation and anonymous contribution, as well as the possibility of withdrawing from the study at any time without reason. 


\section{References}

1. Olsen, P.C.; Curtis, E. Consumer product design. RCA Eng. 2020, 21, 70-71.

2. Cheaitou, A.; Gardoni, M.; Hamdan, S. A decision-making framework for environmentally sustainable product design. Concurr. Eng. Res. Appl. 2019, 27, 295-304. [CrossRef]

3. Stief, P.; Dantan, J.Y.; Etienne, A.; Siadat, A.; Burgat, G. Product design improvement by a new similarity-index-based approach in the context of reconfigurable assembly processes. J. Eng. Des. 2020, 31, 349-377. [CrossRef]

4. Pessôa, M.V.P.; Becker, J.M.J. Smart design engineering: A literature review of the impact of the 4th industrial revolution on product design and development. Res. Eng. Des. 2020, 31, 175-195. [CrossRef]

5. Naderi, E.; Naderi, I.; Balakrishnan, B. Product design matters, but is it enough? Consumers' responses to product design and environment congruence. J. Prod. Brand Manag. 2020, 29, 939-954. [CrossRef]

6. Norman, D.; Ortony, A. Designers and users: Two perspectives on emotion and design. In Proceedings of the Symposium on Foundations of Interaction Design, Lisbon, Portugal, 1-4 November 2006; pp. 1-13.

7. Bloch, P.H. Seeking the ideal form: Product design and consumer response. J. Mark. 1995, 59, 16-29. [CrossRef]

8. AEFJ. Toy Image (Imagen del Juguete). Available online: https://www.aefj.es/paginas/carta-de-imagen-del-juguete (accessed on 20 November 2019).

9. Starks, K. Cognitive behavioral game design: A unified model for designing serious games. Front. Psychol. 2014, 5, 28. [CrossRef]

10. Martínez-Sanz, R. Estrategia comunicativa digital en el museo. El Profesional de la Información 2012, 21, 391-395. [CrossRef]

11. Chadha, C.; Crowe, K.A.; Carmen, C.L.; Patterson, A.E. Exploring an AM-Enabled Combination-of-Functions Approach for Modular Product Design. Designs 2018, 2, 37. [CrossRef]

12. Ocampo, L.A.; Labrador, J.J.T.; Jumao-as, A.M.B.; Rama, A.M.O. Integrated multiphase sustainable product design with a hybrid quality function deployment-Multi-attribute decision-making (QFD-MADM) framework. Sustain. Prod. Consum. 2020, $24,62-78$. [CrossRef]

13. Burton, N.; Galvin, P. Component complementarity and transaction costs: The evolution of product design. Rev. Manag. Sci. 2020, 14, 845-867. [CrossRef]

14. Haziri, L.L.; Sundin, E. Supporting design for remanufacturing-A framework for implementing information feedback from remanufacturing to product design. J. Remanuf. 2020, 10, 57-76. [CrossRef]

15. Quan, H.; Li, S.; Hu, J. Product Innovation Design Based on Deep Learning and Kansei Engineering. Appl. Sci. 2018, 8, 2397. [CrossRef]

16. Morer, P.; Rodríguez-Ferradas, M.I.; Cazón, A. The social role of design (El rol social del diseño). Temes Disseny 2016, 32, 98-109.

17. Edson, J. Lunar Design. 2020. Available online: www.lunar.com (accessed on 15 November 2020).

18. Winter, T. The Social Impact of Design (El Impacto Social del Diseño). 2019. Available online: www.whatdesigncando.com (accessed on 18 September 2020).

19. Nations, U. Sustainable Development Goals. 2015. Available online: https://www.un.org/sustainabledevelopment/ (accessed on 18 September 2020).

20. Keitsch, M.; Prestholt, E. Industrial Design: A profession between engineering and art. In Proceedings of the DS 82: 17th International Conference on Engineering and Product Design Education (E\&PDE15), Great Expectations: Design Teaching, Research \& Enterprise, Loughborough, UK, 3-4 September 2015; pp. 351-356.

21. Vere, I.D. Industrial design 2.0: A renaissance. In Proceedings of the DS 76: E\&PDE 2013, the 15th International Conference on Engineering and Product Design Education, Dublin, Ireland, 5-6 September 2013.

22. Primo, M.C.; Gil-Saura, I.; Frasquet-Deltoro, M. The role of marketing and product design in driving firm's performance. J. Prod. Brand Manag. 2020. [CrossRef]

23. Heitmann, M.; Landwehr, J.R.; Schreiner, T.F.; van Heerde, H.J. Leveraging Brand Equity for Effective Visual Product Design. J. Mark. Res. 2020, 57, 257-277. [CrossRef]

24. Sabir, S.S. Does product design stimulate customer satisfaction? Mediating role of affect. Asia Pac. J. Mark. Logist. 2020, 32, 1255-1268. [CrossRef]

25. Najafi-Tavani, Z.; Mousavi, S.; Zaefarian, G.; Naudé, P. Relationship learning and international customer involvement in new product design: The moderating roles of customer dependence and cultural distance. J. Bus. Res. 2020, 120, 42-58. [CrossRef]

26. Dong, M.; Zeng, X.; Koehl, L.; Zhang, J. An interactive knowledge-based recommender system for fashion product design in the big data environment. Inf. Sci. 2020, 540, 469-488. [CrossRef]

27. Haase, J.; Wiedmann, K.P.; Bettels, J. Sensory imagery in advertising: How the senses affect perceived product design and consumer attitude. J. Mark. Commun. 2020, 26, 475-487. [CrossRef]

28. Weber, T.A. How to Market. Smart Products: Design and Pricing for Sharing Markets. J. Manag. Inf. Syst. 2020, 37, 631-667.

29. Pack, A.T.; Rose Phipps, E.; Mattson, C.A.; Dahlin, E.C. Social impact in product design, an exploration of current industry practices. J. Mech. Des. Trans. ASME 2020, 142, 7. [CrossRef]

30. Armitage, J. Luxury and Visual Culture; Bloomsbury Visual Arts: London, UK; New York, NY, USA; New Delhi, India; Sidney, Australia, 2020; pp. 37-66.

31. Santos, C. The Influence of Advertising on Youth Consumption of Clothing and Footwear Brands: A case study. Int. J. Mark. Commun. New Med. 2016, 4, 85-105. 
32. Lučić, A.; Dabić, M.; Finley, J. Marketing innovation and up-and-coming product and process innovation. Int. J. Entrep. Small Bus. 2019, 37, 434-448. [CrossRef]

33. Dixon, S.M.; Shankar, A. Footwear with feeling: A cultural approach to product development. J. Mark. Manag. 2018, 34, 536-537. [CrossRef]

34. Footwear, W. Yearbook of the World Footwear Sector: Year. 2018 (Anuario del Sector Mundial del Calzado: Año 2018 ). 2019. Available online: http:/ / revistadelcalzado.com/anuario-sector-mundial-calzado-2018/ (accessed on 22 June 2020).

35. Nancarrow, C.; Wright, L.T.; Brace, I. Gaining competitive advantage from packaging and labelling in marketing communications. Br. Food J. 1998, 100, 110-118. [CrossRef]

36. Underwood, R.L.; Ozanne, J.L. Is your package an effective communicator? A normative framework for increasing the communicative competence of packaging. J. Mark. Commun. 1998, 4, 207-220. [CrossRef]

37. Silayoi, P.; Speece, M. The importance of packaging attributes: A conjoint analysis approach. Eur. J. Mark. 2007, 41. [CrossRef]

38. Orth, U.R.; Campana, D.; Malkewitz, K. Formation of consumer price expectation based on package design: Attractive and quality routes. J. Mark. Theory Pract. 2010, 18, 23-40. [CrossRef]

39. Chind, K.; Sahachaisaeree, N. Purchasers' Perception on Packaging Formal Design: A Comparative Case Study on Luxury Goods Merchandizing. Procedia Soc. Behav. Sci. 2012, 42, 436-442. [CrossRef]

40. Azad, N.; Bandad, S.; Hozouri, S. Investigating the effect of packaging design on persuading consumers. Uncertain Supply Chain Manag. 2014, 2, 105-110. [CrossRef]

41. Schoormans, J.P.L.; Robben, H.S.J. The effect of new package design on product attention, categorization and evaluation. J. Econ. Psychol. 1997, 18, 271-287. [CrossRef]

42. Grunert, K.G.; Bredahl, L.; Brunsø, K. Consumer perception of meat quality and implications for product development in the meat sector-A review. Meat Sci. 2004, 66, 259-272. [CrossRef]

43. Underwood, R.L.; Klein, N.M.; Burke, R.R. Packaging communication: Attentional effects of product imagery. J. Prod. Brand Manag. 2001, 10. [CrossRef]

44. Brunner, R.; Emery, S.; Hall, R. Your Brand Is Not Your Logo: It Is an Experience That Lives in Your Customer's Gut; Pearson: London, UK, 2009.

45. Reimann, M.; Zaichkowsky, J.; Neuhaus, C.; Bender, T.; Weber, B. Aesthetic package design: A behavioral, neural, and psychological investigation. J. Consum. Psychol. 2010, 20, 431-441. [CrossRef]

46. Norman, D. Emotional Design: Why We Love (or Hate) Everyday Things; Basic Civitas Books: New York, NY, USA, 2004.

47. Bloch, P.; Brunel, F.; Arnold, T. Individual Differences in the Centrality of Visual Product Aesthetics. J. Consum. Res. 2003, 29, 551-565. [CrossRef]

48. Fugate, D.L. Marketing services more effectively with neuromarketing research: A look into the future. J. Serv. Mark. 2008, 22, 170-173. [CrossRef]

49. Calvert, G.A.; Thesen, T. Multisensory integration: Methodological approaches and emerging principles in the human brain. J. Physiol. Paris 2004, 98, 191-205. [CrossRef]

50. Calvert, G.; Brammer, M. Predicting Consumer Behavior Using Novel Mind-Reading Approaches. IEEE Pulse $2012,3,38-41$. [CrossRef]

51. Hammou, K.; Galib, M.; Melloul, J. The Contributions of Neuromarketing in Marketing Research. J. Manag. Res. 2013, 5, 20. [CrossRef]

52. Glimcher, P.W.; Camerer, C.F.; Fehr, E.; Poldrack, R.A. Neuroeconomics; Academic Press: London, UK, 2009 ; Chapter 1; pp. 1-12.

53. Vecchiato, R.; Roveda, C. Strategic foresight in corporate organizations: Handling the effect and response uncertainty of technology and social drivers of change. Technol. Forecast. Soc. Chang. 2010, 77, 1527-1539. [CrossRef]

54. Morin, C. Neuromarketing: The New Science of Consumer Behavior. Society 2011, 48, 131-135. [CrossRef]

55. Morin, A.J.; Scalas, L.F.; Vispoel, W.; Marsh, H.W.; Wen, Z. The Music Self-Perception Inventory: Development of a short form. Psychol. Music 2016, 44, 915-934. [CrossRef]

56. Fortunato, V.C.R.; Giraldi, J.D.M.E.; de Oliveira, J.H.C. A review of studies on neuromarketing: Practical results, techniques, contributions and limitations. J. Manag. Res. 2014, 6, 201. [CrossRef]

57. Crone, E.A.; Ridderinkhof, K. The developing brain: From theory to neuroimaging and back. Dev. Cogn. Neurosci. 2011, 1, 101-109. [PubMed]

58. Lăzăroiu, G.; Pera, A.; Ștefănescu-Mihăilă, R.O.; Mircică, N.; Negurită, O. Can Neuroscience Assist Us in Constructing Better Patterns of Economic Decision-Making? Front. Behav. Neurosci. 2017, 11, 188. [CrossRef] [PubMed]

59. Reimann, M.; Schilke, O.; Weber, B.; Neuhaus, C.; Zaichkowsky, J. Functional magnetic resonance imaging in consumer research: A review and application. Psychol. Mark 2011, 28, 608-637. [CrossRef]

60. Madan, C.R. Neuromarketing: The next step in market research? Eureka 2010, 1, 34-42. [CrossRef]

61. Ariely, D. Predictably Irrational: The Hidden Forces That Shape Our Decisions; Harper Audio: New York, NY, USA, 2008; pp. 107-125.

62. Cuesta-Cambra, U.; Nino-Gonzalez, J.I.; Rodriguez-Terceno, J. The Cognitive Processing of an Educational App with Electroencephalogram and "Eye Tracking". Comunicar 2017, 25, 41-50. [CrossRef]

63. Juárez-Varón, D.; Tur-Viñes, V.; Rabasa-Dolado, A.; Polotskaya, K. Adaptive Machine Learning Methodology Applied to Neuromarketing Analysis: Prediction of Consumer Behaviour Regarding the Key Elements of the Packaging Design of an Educational Toy. Soc. Sci. 2020, 9, 162. [CrossRef] 
64. Juarez, D.; Tur-Viñes, V.; Mengual, A. Neuromarketing Applied to Educational Toy Packaging. Front. Psychol. $2020,11,2077$. [CrossRef] [PubMed]

65. Mengual-Recuerda, A.; Tur-Viñes, V.; Juárez Varón, D. Neuromarketing in Haute Cuisine Gastronomic Experiences. Front. Psychol. 2020, 11, 1772. [CrossRef] [PubMed]

66. Gould, D.; Krane, V. The Arousal-Athletic Performance Relationship: Current Status and Future Directions. In Advances in Sport Psychology; Human Kinetics Publishers: Champaign, IL, USA, 1992; pp. 119-142.

67. Añaños-Carrasco, E. Eyetracker technology in elderly people: How integrated television content is paid attention to and processed. Comunicar 2015, 23, 75-83. [CrossRef]

68. Damasio, A.R. Descartes's Mistake: The Reason for Emotions (El Error de Descartes: La Razón de las Emociones); Booket: Barcelona, Spain, 1994.

69. Martínez-Selva, J.M.; Sánchez-Navarro, J.P.; Bechara, A.; Román, F. Brain mechanisms in decision making. (Mecanismos cerebrales de la toma de decisiones). Neurol. J. (Revista de Neurología) 2006, 42, 411-418. [CrossRef]

70. Glimcher, P.W.; Camerer, C.F.; Fehr, E.; Poldrack, R.A. Introduction: A brief history of neuroeconomics. In Neuroeconomics; Elsevier: Amsterdam, The Netherlands, 2009; pp. 1-12.

71. Mendrek, A. Is it important to consider sex and gender in neurocognitive studies? Front. Psychiatry 2015, 6, 83. [CrossRef] [PubMed]

72. Zhang, X.; Yuan, S.M.; Chen, M.D.; Liu, X. A complete system for analysis of video lecture based on eye tracking. IEEE Access 2018, 6, 49056-49066. [CrossRef]

73. Orquin, J.L.; Loose, S.M. Attention and choice: A review on eye movements in decision making. Acta Psychol. 2013, 144, 190-206. [CrossRef] [PubMed]

74. Balconi, M.; Sebastiani, R.; Galeone, A.B.; Angioletti, L. Sustainability in the fashion luxury branding. Using neuroscience to understand consumers' intentions towards sustainable eco-luxury items. Neuropsychol. Trends 2020, 65-74. [CrossRef]

75. Hu, H.Y.; Jasper, C.R. Understanding the Shopping Experience and Its Implications for Malls as Marketing Media Attracting and Retaining Customers through Fashion, Service, and Improved Food Options. J. Advert. Res. 2018, 58, 151-164. [CrossRef]

76. Ohme, R.; Matukin, M.; Pacula-Lesniak, B. Biometric measures for interactive advertising research. J. Interact. Advert. 2011, 11, 60-72. [CrossRef]

77. Duchowski, A.T. Eye Tracking Methodology; Springer: London, UK, 2007; Volume 328, pp. 2-3.

78. Martínez-Ruiz, M.P.; Gómez-Suárez, M.; Jiménez-Zarco, A.I.; Izquierdo-Yusta, A. From Consumer Experience to Affective Loyalty: Challenges and Prospects in the Psychology of Consumer Behavior 3.0. Front. Psychol. 2017, 8, 2224. [CrossRef] [PubMed]

79. Moreira, A.C.; Fortes, N.; Santiago, R. Influence of sensory stimuli on brand experience, brand equity and purchase intention. J. Bus. Econ. Manag. 2017, 18, 68-83. [CrossRef]

80. Elder, R.S.; Aydinoglu, N.Z.; Barger, V.; Caldara, C.; Chun, H.E.; Lee, C.J.; Mohr, G.S.; Stamatogiannakis, A. A Sense of Things to Come Future Research Directions in Sensory Marketing. In Sensory Marketing: Research on the Sensuality of Products; Krishna, A., Ed.; Routledge: Abington, UK, 2011; pp. 361-376.

81. Lenderman, M. Experiential Marketing: The Brand Revolution (Marketing Experiencial: La Revolución de las Marcas); ESIC Editorial: Pozuelo de Alarcón, Spain, 2008.

82. Blazquez, M. Fashion Shopping in Multichannel Retail: The Role of Technology in Enhancing the Customer Experience. Int. J. Electron. Commer. 2014, 18, 97-116. [CrossRef]

83. Enax, L.; Weber, B.; Ahlers, M.; Kaiser, U.; Diethelm, K.; Holtkamp, D.; Faupel, U.; Holzmüller, H.H.; Kersting, M. Food packaging cues influence taste perception and increase effort provision for a recommended snack product in children. Front. Psychol. 2015, 6, 882. [CrossRef] [PubMed]

84. Douce, L.; Janssens, W. The Presence of a Pleasant Ambient Scent in a Fashion Store: The Moderating Role of Shopping Motivation and Affect Intensity. Environ. Behav. 2013, 45, 215-238. [CrossRef]

85. Kim, H.S.; Hong, H. Fashion Leadership and Hedonic Shopping Motivations of Female Consumers. Cloth. Text. Res. J. 2011, 29, 314-330. [CrossRef] 